\title{
STABILITY-INDICATING HPLC AND UV SPECTROPHOTOMETRIC DETERMINATION OF SOFOSBUVIR IN PURE FORM AND TABLETS
}

\author{
BY \\ Ahmad Abdelhalim Abouserie Mohamad* \\ FROM \\ Pharmaceutical Analytical Chemistry Department, Faculty of Pharmacy, Al-Azhar \\ University, 11751, Nasr City, Cairo, Egypt
}

\begin{abstract}
Four simple, sensitive, accurate and precise stability-indicating methods were developed for determination of sofosbuvir (SFB) in pure form as well as in its pharmaceutical preparation and in presence of its alkaline degradate. The first method is an HPLC stability-indicating method, where the intact drug (SFB), the internal standard (atorvastatin) and SFB degradation product were separated on a Athena $\mathrm{C}_{18}(250 \mathrm{~mm} \mathrm{X}$ $4.6 \mathrm{~mm}$ ID, $5 \mu \mathrm{m}$ particle size) column using methanol-water $(70: 30, \mathrm{v} / \mathrm{v})$ as a mobile phase at a flow rate of $1 \mathrm{ml} / \mathrm{min}$ and UV detection at $260 \mathrm{~nm}$. The second method is the ratio difference method, where the UV absorption spectra of different concentrations of SFB were divided by the absorption spectrum of a certain concentration $(30 \mu \mathrm{g} / \mathrm{ml})$ of its degradation product (divisor) to get the ratio difference spectra. Afterwards, the difference in peak amplitudes between 270 and $245 \mathrm{~nm}$ were measured. The third method is the ratio derivative method, where the amplitudes of first derivative of the obtained ratio difference spectra were measured at $282 \mathrm{~nm}$. The fourth method is the mean centering of ratio difference spectra, where the amplitudes of the mean centered ratio difference spectra were measured at $262.6 \mathrm{~nm}$. The calibration curves were linear over the concentration range of $5-35 \mu \mathrm{g} / \mathrm{ml}$ for all methods. The proposed methods can selectively analyse the drug in presence of up to $86 \%$ of its degradation product with mean recoveries of $100.66 \pm 1.310,101.04 \pm 1.662,101.06 \pm 1.026$ and $99.92 \pm 1.374$ for the four methods, respectively. These methods were validated and successfully applied for the determination of SFB in its commercial preparation. Moreover, the obtained results were statistically compared with those of the reported method by applying t-test and Ftest at $95 \%$ confidence level. It was found that no significant differences were observed regarding accuracy and precision.
\end{abstract}

\section{KEY WORDS}

Sofosbuvir, Stability-indicating, Ratio difference, Ratio derivative, Mean centering ratio spectra.

\section{INTRODUCTION}

SFB (Fig. 1) is $\quad(S)$-Isopropyl 2-((S)-(((2R,3R,4R,5R)-5-(2,4-dioxo-3,4 dihydropyrim-idin-1(2H)-yl)-4-fluoro-3-hydroxy-4-methyltetrahydrofuran-2-yl) (methoxy) - (phenoxy)- phosphorylamino)propanoate. It is a white crystalline solid with a solubility of $\geq 2 \mathrm{mg} / \mathrm{mL}$ in $\mathrm{pH}$ range of $2-7.7$ at $37{ }^{\circ} \mathrm{C}$, freely soluble in methanol and 
slightly soluble in water. It is a nucleotide analog inhibitor of hepatitis C virus NS5B polymerase. It is indicated for the treatment of chronic hepatitis $\mathrm{C}$ infection as a component of a combination antiviral treatment regimen (RxList, 2015)

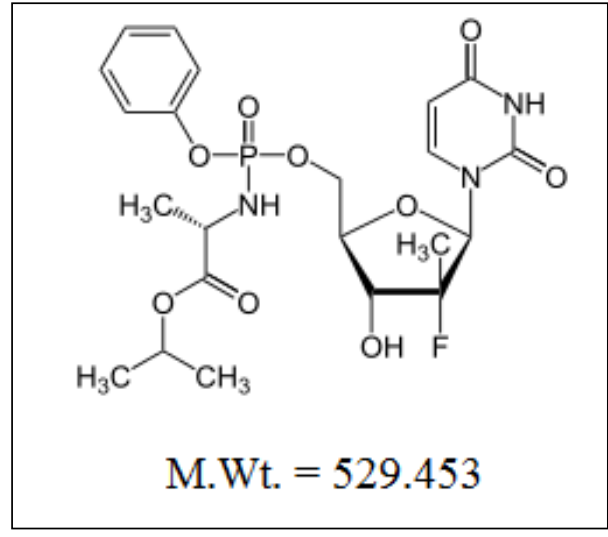

Figure 1: Structural formula of SFB

To our knowledge there is no analytical methods have been published for the analysis of SFB neither in its pharmaceutical preparation nor in presence of its alkaline degradation product.

HPLC is an important qualitative and quantitative technique, generally used to separate, identify, and quantify the active compounds in pharmaceutical and biological samples (Martin and Guiochon, 2005). Reversed-phase chromatography is the most commonly used separation mode in HPLC. The reasons for this include the simplicity, versatility and scope of the reversed-phase method as it is able to handle compounds of a diverse polarity and molecular mass (Willard and Dean, 1986; Harvey, 2000; Connors, 2005).

Under computer-controlled instrumentation, first derivative of ratio spectra, ratio difference and mean centering of the ratio spectra methods are playing a very important role in the analysis of binary mixtures without previous separation by UV-VIS spectrophotometry (El-Ragehy et al., 2002; Issa et al., 2011; Abdallah and Badawey, 2011; EL-Bagary et al., 2011; Elzanfaly et al., 2012; Lotfy and Hagazy, 2012; Darwish et al., 2013; Lotfy et al., 2012; Belal et al., 2013; Darwish et al., 2011; Afkhami and Bahram, 2004; Afkhami and Bahram, 2005; Afkhami and Bahram, 2006)

In this work; HPLC, UV ratio difference, UV ratio derivative and UV ratio mean centering methods were applied to the selective determination of SFB in presence of its alkaline degradate. The proposed procedures were successfully applied for determination of SFB in bulk powder and in its pharmaceutical dosage form. 


\section{MATERIALS AND METHODS}

\section{Apparatus}

- HPLC, LDC Analytical (Milton Roy, USA), equipped with Diode-array UV-Visible detector and auto sampler injector. The chromatographic analysis was carried out using (EZ Chrom Elit) data analysis program.

- Shimadzu UV-Vis. 1800 Spectrophotometer, (Tokyo, Japan), equipped with $10 \mathrm{~mm}$ matched quartz cells.

- Hot plate, Torrey pines scientific (USA).

- Jenway pH meter, 3510 (USA).

- UV lamp with short wavelength $254 \mathrm{~nm}$ (Vilber Lourmat, France)

- Precoated TLC plates silica gel $60 \mathrm{GF}_{254}(20 \mathrm{x} 20 \mathrm{~cm}), 0.22 \mathrm{~mm}$ thickness (Fluka, Chemie, Switzerland).

\section{Pure sample}

- SFB was kindly supplied by Al Andalous for Pharmaceutical Industries, 6th of October, Giza, Egypt. The purity was assigned as 99.15\%.

- Atorvastatin was kindly supplied by Amoun Pharmaceutical Company, Cairo, Egypt. The purity was assigned as $99.25 \%$.

\section{Pharmaceutical preparation}

SOVALDI $^{\circledR}$ tablets, each tablet contains $400 \mathrm{mg}$ of SFB (B.No. 100924, manufactured by Gilead Sciences, USA), purchased from local market.

\section{Reagents and solvents}

All chemicals and reagents used throughout the work were of analytical grade.

- Water used throughout the procedures was freshly double distilled.

- Methanol, HPLC grade (Sigma-Aldrich, USA).

- Acetonitrile, HPLC grade (Sigma-Aldrich, USA).

- Chloroform, HPLC grade (Sigma-Aldrich, USA).

- Glacial acetic acid (Fisher Scientific, USA).

- Sodium hydroxide (El-Nasr Company, Egypt), prepared as $1 \mathrm{M}$ aqueous solution.

- Hydrochloric acid (El-Nasr Company, Egypt), prepared as $1 \mathrm{M}$ aqueous solution.

- Potassium dihydrogen orthophosphate (El-Nasr Company, Egypt)

- Orthophosphoric acid 85\% (peypin, France).

- Phosphate buffer pH 3.5 (British Pharmacopoeia, 2012).

\section{Standard solutions:}

\section{Standard solution of intact SFB}

A standard solution of SBF $(100 \mu \mathrm{g} / \mathrm{ml})$ was prepared by dissolving $10 \mathrm{mg}$ of SFB in $50 \mathrm{ml}$ of methanol and complete to $100 \mathrm{ml}$ with the same solvent.

\section{Standard solution of atorvastatin (Internal standard):}

A standard solution of atorvastatin $(100 \mu \mathrm{g} / \mathrm{ml})$ was prepared by dissolving $10 \mathrm{mg}$ of atorvastatin in $50 \mathrm{ml}$ of methanol and complete to $100 \mathrm{ml}$ with the same solvent. 


\section{Standard solution of degraded sample:}

$100 \mathrm{mg}$ of pure SFB powder were refluxed with $50 \mathrm{ml} 1 \mathrm{M} \mathrm{NaOH}$ for 38 hours. After cooling, the solution was neutralized by $1 \mathrm{M} \mathrm{HCl}$, evaporated to dryness under vacuum. The obtained residue was extracted with methanol $(2 \times 10 \mathrm{ml})$, filtered into a $100-\mathrm{mL}$ volumetric flask and diluted with methanol to obtain a stock solution labeled to contain degradate derived from $1 \mathrm{mg} / \mathrm{ml}$ of SFB. On the other hand, SFB showed no considerable degradation when acidic, oxidative and UV degradation methods had been used instead of alkaline.

\section{Procedures}

\section{Construction of the calibration curve (General procedure)}

\section{HPLC method}

\section{Chromatographic conditions}

At ambient temperature, isocratic separation was carried out on Athena C18 (250 X 4.6 X 5 $\mu \mathrm{m}$ particle size) using mobile phase consists of methanol: water (70:30, v/v). The mobile phase was degassed by a degasser before pumped at flow rate $1 \mathrm{ml} / \mathrm{min}$. The injected volume of the standard solution was $20 \mu \mathrm{l}$ and UV detection at $260 \mathrm{~nm}$.

\section{Linearity}

Aliquots of standard SFB solution $(100 \mu \mathrm{g} / \mathrm{ml})$ containing $(50-350 \mu \mathrm{g})$ of intact SFB were transferred into a series of $10 \mathrm{ml}$ volumetric flasks containing (150 $\mu \mathrm{g})$ of atorvastatin (internal standard) and adjusted to volume with mobile phase. Into HPLC column, $20 \mu \mathrm{l}$ were injected from each concentration under the described chromatographic conditions. Calibration graph was constructed by plotting the peak area ratio against the corresponding drug concentration in $\mu \mathrm{g} / \mathrm{ml}$ and the regression equation was derived.

\section{Ratio methods}

Different aliquots of SFB standard solution ranging from (50-350) $\mu \mathrm{g}$ were transferred to a $10-\mathrm{ml}$ volumetric flasks and completed to volume with methanol. The absorption spectra (from 200 to $400 \mathrm{~nm}$ ) of these solutions were recorded using methanol as a blank, and then divided by the spectrum of SFB degradates solution (30 $\mu \mathrm{g} / \mathrm{ml})$.

\section{A. Ratio difference method}

The difference in the peak amplitudes $(\Delta P)$ at the ratio spectra was measured at 270 and $245 \mathrm{~nm}\left(\Delta P_{270-245} \mathrm{~nm}\right)$. The measured $\Delta P$ values versus the final concentrations in $\mu \mathrm{g} / \mathrm{ml}$ were plotted to get the calibration graph and the regression equation was derived.

\section{B. First derivative of ratio spectra method}

The first derivative corresponding to each ratio spectrum was recorded, using $\Delta \lambda$ $=8 \mathrm{~nm}$. The amplitude values at $282 \mathrm{~nm}$ were measured. The measured amplitude 
values versus the final concentrations in $\mu \mathrm{g} / \mathrm{ml}$ were plotted to get the calibration graph and the regression equation was derived.

\section{Mean centering of ratio spectra method}

The ratio spectra (from 200 to $400 \mathrm{~nm}$ ) were mean centered and the mean centered values were measured at $262.6 \mathrm{~nm}$. The measured mean centered values versus the final concentrations in $\mu \mathrm{g} / \mathrm{ml}$ were plotted to get the calibration graph and the regression equation was derived.

\section{Analysis of pharmaceutical preparation}

Five tablets of SOVALDI ${ }^{\circledR} 400 \mathrm{mg}$ were weighed and finely powdered. An accurately weighed amount of the powder equivalents to $10 \mathrm{mg}$ was dissolved in methanol, filtered into $100 \mathrm{ml}$ volumetric flask and the volume was completed to volume with methanol to obtain a solution labeled to contain $100 \mu \mathrm{g} / \mathrm{ml}$ of SFB. Transfer aliquots covering the working concentration range into $10 \mathrm{ml}$ volumetric flasks. Proceed as described under "General Procedure" for each method. Determine the content of the tablets either from the calibration curve or using the corresponding regression equation.

\section{RESULTS AND DISCUSSION}

\section{Degradation of SFB}

Accelerated degradation method of SFB was achieved upon heating under reflux with $1 \mathrm{M}$ sodium hydroxide for 38 hours. Later on, complete degradation of SFB was confirmed by TLC. For this purpose, the solution after reflux with $1 \mathrm{M}$ sodium hydroxide for 38 hours was cooled, neutralized with $1 \mathrm{M}$ hydrochloric acid, evaporated under vacuum till dryness, extracted with methanol and filtered. The obtained solution was tested by TLC on silica gel $60 \mathrm{GF}_{254}$ plates. Separation of the intact drug and its corresponding degradate was achieved by using mobile phase consists of methanol chloroform - glacial acetic acid (50: 50: 0.1 by volume) and UV detection at $254 \mathrm{~nm} . \mathrm{R}_{\mathrm{f}}$ values of the intact SFB and its corresponding degradate were 0.26 and 0.61 , respectively.

\section{HPLC method}

In the present study, a simple and sensitive reversed phase HPLC procedure was suggested for the selective quantitative determination of SFB in presence of its alkaline degradation product.

Different chromatographic conditions affecting the separation were tested taking in consideration the resolution between the drug, its degradation product and the internal standard. Several mobile phases were tried in order to separate the intact drug from its degradate and the internal standard including methanol: water in different ratios. Good separation was carried out on Athena C18 ( 250 X 4.6 X 5 $\mu$ m particle size) column using a mobile phase consists of methanol: water $(70: 30, \mathrm{v} / \mathrm{v})$ at flow rate $1 \mathrm{ml}$ $\min ^{-1}$ and UV detection at $260 \mathrm{~nm}$. 
In HPLC chromatogram, showed in Figure 2, the peak of intact SFB, its degradation product and the internal standard were clearly separated and their corresponding peaks were sharply developed at reasonable retention times of $2.8 \pm 0.02$, $4.8 \pm 0.03$ and $6.9 \pm 0.03$ minutes for intact SFB, atorvastatin (internal standard) and degradation product respectively.

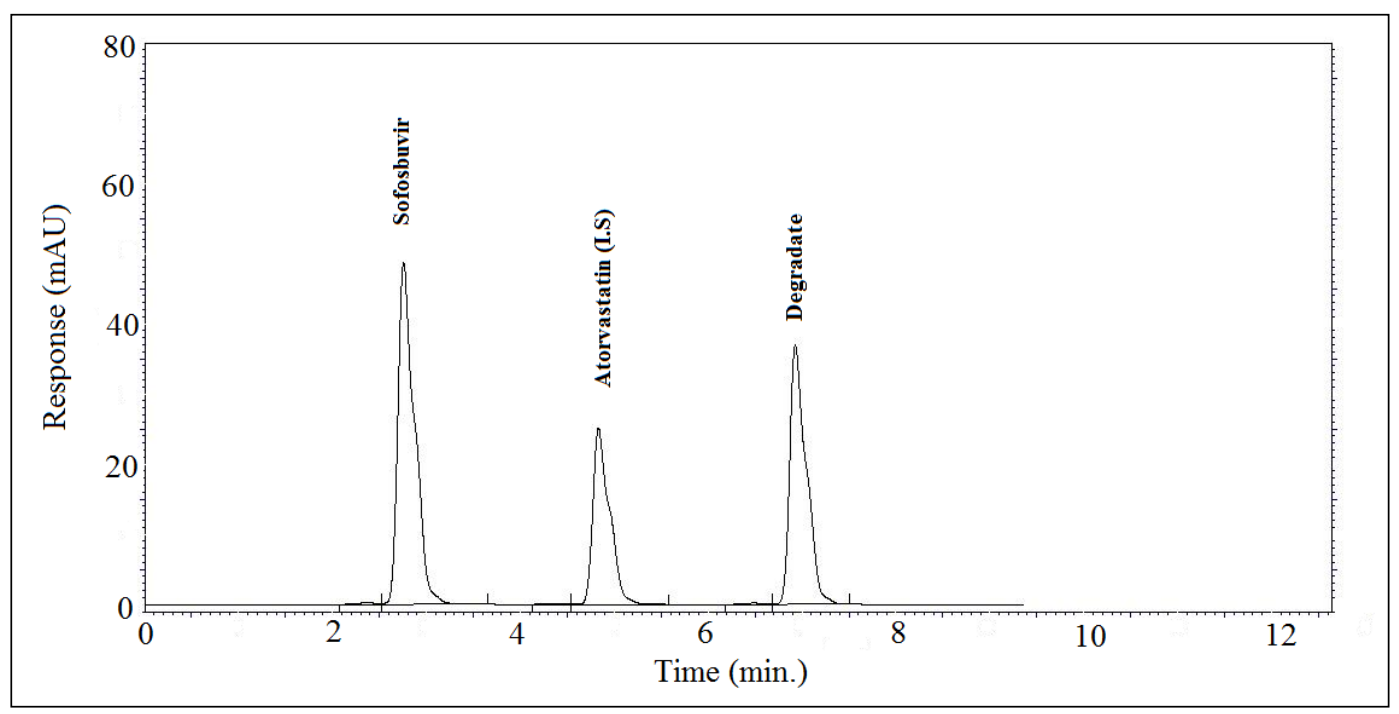

Figure 2. HPLC chromatogram of a mixture of intact SFB $(35 \mu \mathrm{g} / \mathrm{ml})$, atorvastatin as internal standard $(15 \mu \mathrm{g} / \mathrm{ml})$ and degradation product $(30 \mu \mathrm{g} / \mathrm{ml})$.

\section{Ratio difference method}

The zero-order absorption spectra of SFB and its alkaline degradate (Fig. 3) show severe overlap, which does not permit direct determination of SFB in presence of its degradate.

In this method, the absorption spectra of SFB were divided by a suitable absorption spectrum of its degradation product as a divisor to get the ratio spectra. The difference in peak amplitudes between two selected wavelengths in the ratio spectra was found to be proportional with the concentration of the drug without interference from its degradation product (Fig. 4). The method comprises two critical steps, the first is the choice of the divisor; the selected divisor should compromise between minimal noise and maximum sensitivity. The divisor concentrations of $30 \mu \mathrm{g} / \mathrm{ml}$ gave the best results. The second critical step is the choice of the wavelengths at which measurements are to be recorded. Any two wavelengths can be chosen provided that they exhibit different amplitudes in the ratio spectrum and give good linearity at each wavelength individually. The best results were obtained at 245 and $270 \mathrm{~nm}\left(\Delta P_{270-245} \mathrm{~nm}\right)$.

\section{First derivative of ratio spectra method}

In this method, the absorption spectra of SFB were divided by a suitable absorption spectrum of its degradation product as a divisor to get the ratio spectra. By application of the first- derivative to these ratio spectra, SFB can be quantitatively determined at $282 \mathrm{~nm}$ without any interference from its degradation product (Figs. 5, 6). 
Careful choice of the divisor and the working wavelength were of great importance. The divisor concentration of $30 \mu \mathrm{g} / \mathrm{ml}$ was found to be the best. It produces minimum noise and gives better results in accordance with selectivity.

\section{Mean centering of ratio spectra method}

In this method, the absorption spectra of SFB were divided by a suitable absorption spectrum of its degradation product as a divisor to get the ratio spectra. The obtained ratio spectra were mean centered. The mean centered values at $262.6 \mathrm{~nm}$ was found to be proportional with the concentrations of the drug without interference from its degradation product (fig. 7). Careful choice of the divisor concentration was of great importance. The divisor concentrations of $30 \mu \mathrm{g} / \mathrm{ml}$ gave the best results in accordance with selectivity.

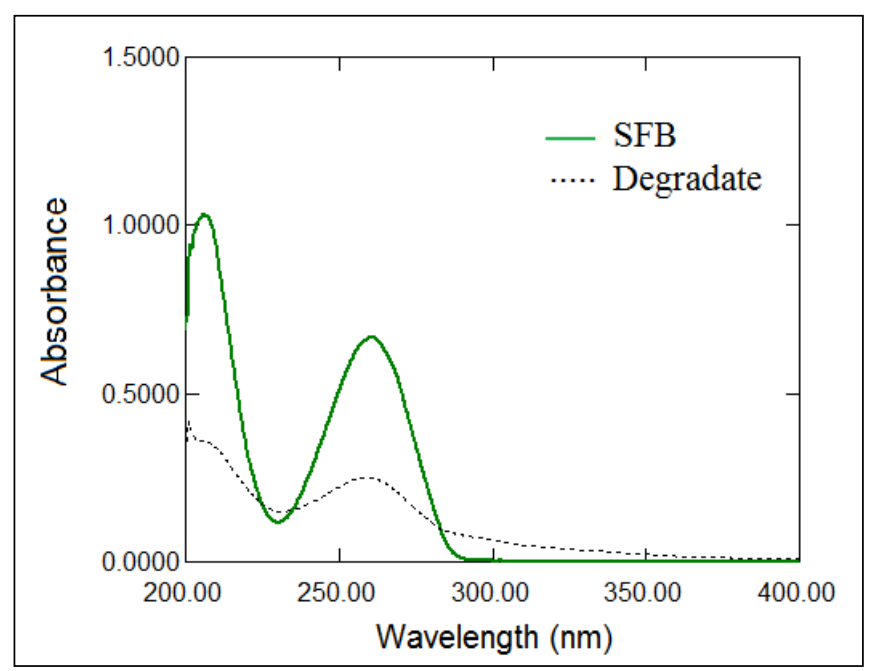

Figure (3): Absorption spectra of SFB $(30 \mu \mathrm{g} / \mathrm{ml})$ and its alkaline degradate $(30 \mu \mathrm{g} / \mathrm{ml})$.

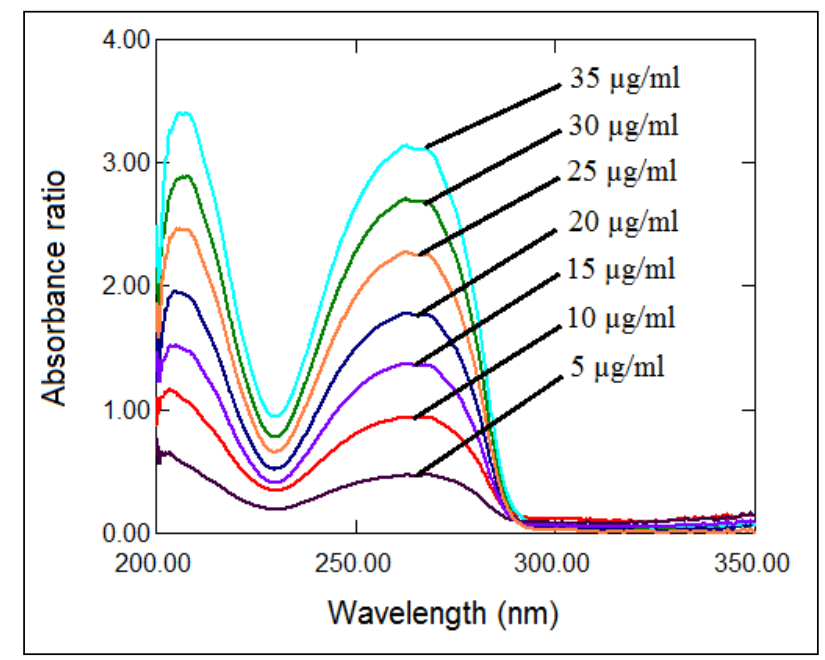

Figure (4): Ratio spectra of SFB at various concentrations using $30 \mu \mathrm{g} / \mathrm{ml}$ of alkaline degradate as a divisor. 


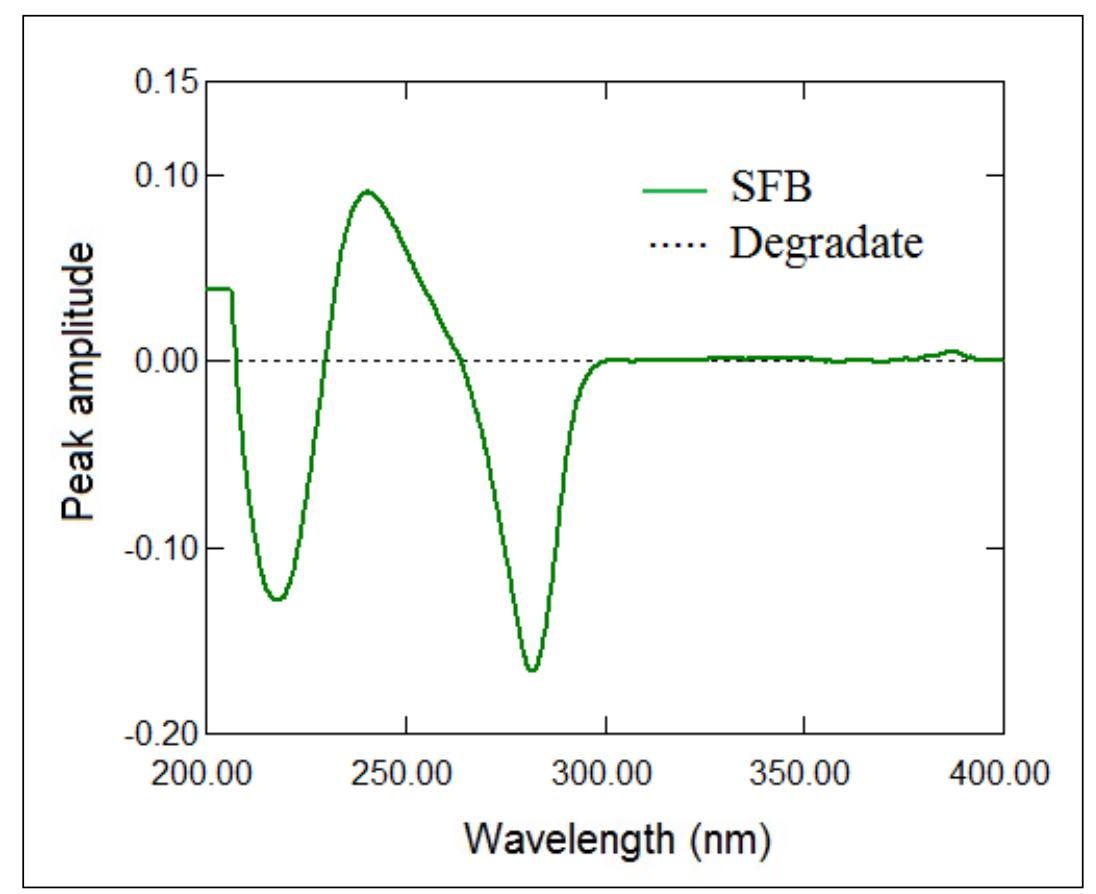

Figure (5): First derivative of the ratio spectra of SFB (30 $\mu \mathrm{g} / \mathrm{ml})$ and its alkaline degradate $(30 \mu \mathrm{g} / \mathrm{ml})$ using $30 \mu \mathrm{g} / \mathrm{ml}$ of degradate as a divisor.

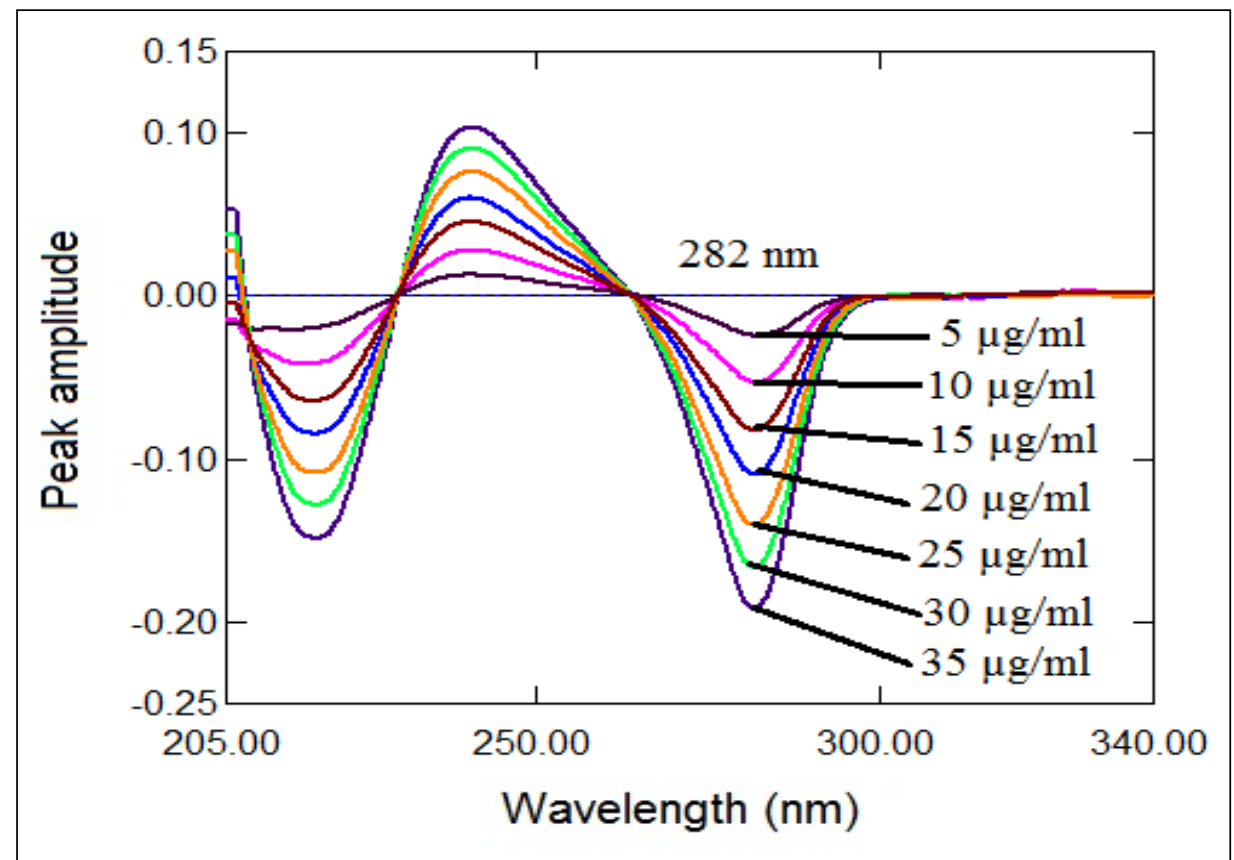

Figure (6): First derivative of the ratio spectra of SFB at various concentrations using $30 \mu \mathrm{g} / \mathrm{ml}$ of degradate as a divisor. 


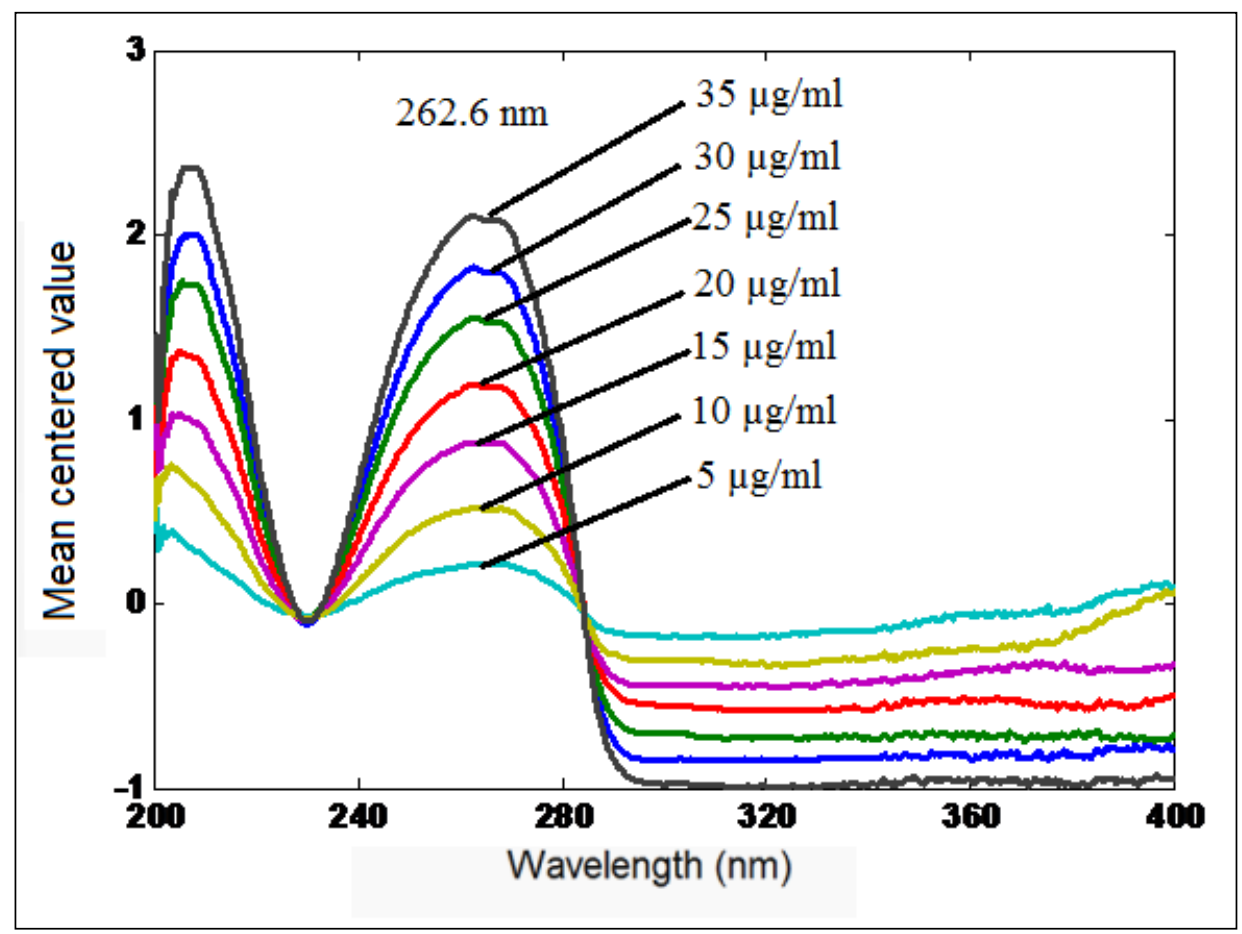

Figure (7): Mean centering of the ratio spectra of SFB at various concentrations using $30 \mu \mathrm{g} / \mathrm{ml}$ of degradate as a divisor.

\section{Validation of the methods (ICH, 2005)}

\section{Linearity and range}

Under the described experimental conditions, the calibration graphs for the methods were constructed by plotting the response versus drug concentrations in $\mu \mathrm{g} / \mathrm{ml}$. The regression plots were found to be linear over the range of $5-35 \mu \mathrm{g} / \mathrm{ml}$ for the four methods. Linearity ranges, regression equations, intercepts, slopes and correlation coefficients for the calibration were listed in Table 1.

\section{Limits of detection and quantitation}

The limit of detection (LOD) and the limit of quantitation (LOQ) were calculated from the following equations:

$$
\begin{aligned}
& \mathrm{LOD}=3.3 \sigma / \mathrm{S} \\
& \mathrm{LOD}=10 \sigma / \mathrm{S}
\end{aligned}
$$

Where $\sigma$ is the standard deviation of $y$-intercepts of regression lines and $S$ is the slope of the calibration curve.

The small values of LOD and LOQ (Table 1) indicate good sensitivity.

\section{Accuracy and precision}

Three replicate determinations of three different concentrations of SFB in pure form within linearity range for each method were performed in the same day (intra-day) 
and in three successive days (inter-day). Accuracy as recovery percent ( $\mathrm{R} \%)$ and precision as percentage relative standard deviation (RSD\%) were calculated (Table 2). The small values of RSD\% indicate high precision of the methods. Morever, the good $\mathrm{R} \%$ confirms excellent accuracy.

\section{Specificity}

The specificity of the proposed methods were assured by applying the laboratory prepared mixtures of the intact drug together with its degradation product. The proposed methods were adopted for the specific determination of intact SFB in presence of up to $86 \%$ of its degradate with mean recoveries of $100.66 \pm 1.310,101.04 \pm 1.662$, $101.06 \pm 1.026$ and $99.92 \pm 1.374$ for HPLC, ratio difference, ratio derivative and mean centering methods respectively (Table 3 ).

\section{System suitability}

System suitability test for HPLC method was applied to a representative chromatogram to check various parameters such as the number of theoretical plates $(\mathrm{N})$, resolution factor $(\mathrm{R})$, capacity factor $\left(\mathrm{K}^{-}\right)$, tailing factor $(\mathrm{T})$ and selectivity factor $(\alpha)$. The results obtained revealed that the chromatographic conditions described here allow complete base line separation between drug, its degradate and the internal standard peaks with minimum tailing.

\section{Robustness}

The robustness of the HPLC method was evaluated by slight changes in the chromatographic conditions such as flow rate $( \pm 0.1 \mathrm{ml} / \mathrm{min}$. $)$ and mobile phase contents ratio $( \pm 3 \%)$. It was found that; these minor changes did not affect the system suitability parameters, confirming robustness of the procedure.

The robustness of the three ratio methods was evaluated by slight changes in the optimum conditions such as divisor concentration $( \pm 0.2 \mu \mathrm{g} / \mathrm{ml})$ and wavelength at which measurements done $( \pm 0.2 \mathrm{~nm})$. It was found that; these minor changes did not affect the results, confirming robustness of the procedures.

\section{Stability of standard solutions}

The stability of standard solutions of SFB and the internal standard (atorvastatin) were determined by repeated analysis of solutions stored either at room temperature or in refrigerator at different time intervals and comparing the responses (peak areas) with those of freshly prepared standard solutions. From the results, it was found that, both SFB and atorvastatin standard solutions were stable for at least 3 and 7 days when stored at room temperature and in refrigerator, respectively.

\section{Pharmaceutical Applications}

The proposed methods were applied to the determination of SFB in SOVALDI ${ }^{\circledR}$ tablets. The results were validated by comparison to a previously reported method (Al-Andalous Company). No significant difference was found by applying t-test and F-test at 95\% confidence level (Armitage, 1994), indicating good accuracy 
and precision of the proposed methods for the analysis of the studied drug in its pharmaceutical dosage form (Table 4).

Table (1): Spectral data for determination of SFB by the proposed methods:

\begin{tabular}{|c|c|c|c|c|}
\hline Parameters & HPLC & $\begin{array}{c}\text { Ratio } \\
\text { difference }\end{array}$ & $\begin{array}{c}\text { Ratio } \\
\text { derivative }\end{array}$ & $\begin{array}{c}\text { Mean } \\
\text { centering }\end{array}$ \\
\hline Wavelength $(\mathrm{nm})$ & 260 & 270 and 245 & 282 & 262.6 \\
\hline Linearity range $\left(\mu \mathrm{gml}^{-1}\right)$ & $5-35$ & $5-35$ & $5-35$ & $5-35$ \\
\hline LOD $\left(\mu \mathrm{gml}^{-1}\right)$ & 0.534 & 0.665 & 0.555 & 0.499 \\
\hline LOQ $\left(\mu \mathrm{gml}^{-1}\right)$ & 1.620 & 2.014 & 1.680 & 1.511 \\
\hline $\begin{array}{c}\text { Regression equation } \\
\text { Slope }(b)\end{array}$ & 0.0654 & 0.0235 & 0.0057 & 0.0647 \\
Intercept $(a)$ & 0.0268 & -0.0014 & -0.0035 & -0.1103 \\
\hline Correlation coefficient $\left(r^{2}\right)$ & 0.9997 & 0.9996 & 0.9997 & 0.9998 \\
\hline
\end{tabular}

$* y=a+b x$ where $y$ is the response and $x$ is the concentration in $\mu \mathrm{gml}^{-1}$.

Table (2): Intraday and interday accuracy and precision for the determination of SFB by the proposed methods:

\begin{tabular}{|c|c|c|c|c|c|c|c|}
\hline \multirow{2}{*}{$\begin{array}{l}\overrightarrow{0} \\
\frac{0}{0} \\
\sum\end{array}$} & \multirow[t]{2}{*}{$\begin{array}{l}\text { Conc } \\
\mu \underset{1}{\operatorname{gg} \cdot \mathrm{ml}^{-}}\end{array}$} & \multicolumn{3}{|c|}{ Intraday } & \multicolumn{3}{|c|}{ Interday } \\
\hline & & $\begin{array}{c}\text { Found } \\
\text { Conc. } \pm \mathrm{SD}\end{array}$ & $\begin{array}{c}\text { Accurac } \\
\mathrm{y} \\
(\mathrm{R} \%)\end{array}$ & $\begin{array}{c}\text { Precision } \\
\text { (RSD\%) }\end{array}$ & $\begin{array}{c}\text { Found } \\
\text { Conc. } \pm \text { SD }\end{array}$ & $\begin{array}{c}\text { Accura } \\
\text { cy } \\
(\mathrm{R} \%)\end{array}$ & $\begin{array}{c}\text { Precisio } \\
\mathrm{n} \\
(\mathrm{RSD} \%)\end{array}$ \\
\hline \multirow{3}{*}{ 坒 } & 10 & $10.13 \pm 0.054$ & 101.31 & 0.536 & $10.04 \pm 0.098$ & 100.41 & 0.978 \\
\hline & 20 & $20.12 \pm 0.241$ & 100.62 & 1.200 & $20.09 \pm 0.257$ & 100.44 & 1.277 \\
\hline & 30 & $29.81 \pm 0.274$ & 99.37 & 0.920 & $29.79 \pm 0.128$ & 99.30 & 0.428 \\
\hline \multirow{3}{*}{. } & 10 & $9.99 \pm 0.085$ & 99.94 & 0.849 & $10.00 \pm 0.077$ & 99.97 & 0.770 \\
\hline & 20 & $20.01 \pm 0.217$ & 100.04 & 1.085 & $20.05 \pm 0.236$ & 100.25 & 1.179 \\
\hline & 30 & $30.28 \pm 0.209$ & 100.93 & 0.689 & $30.18 \pm 0.337$ & 100.58 & 1.116 \\
\hline \multirow{3}{*}{ : } & 10 & $10.06 \pm 0.095$ & 100.62 & 0.944 & $10.04 \pm 0.101$ & 100.37 & 1.007 \\
\hline & 20 & $20.14 \pm 0.259$ & 100.68 & 1.286 & $20.11 \pm 0.245$ & 100.56 & 1.217 \\
\hline & 30 & $29.94 \pm 0.302$ & 99.80 & 1.008 & $30.11 \pm 0.229$ & 100.38 & 0.760 \\
\hline \multirow{3}{*}{ 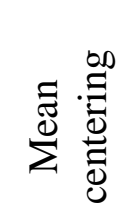 } & 10 & $9.84 \pm 0.080$ & 98.39 & 0.812 & $9.83 \pm 0.090$ & 98.33 & 0.914 \\
\hline & 20 & $20.02 \pm 0.159$ & 100.09 & 0.792 & $20.05 \pm 0.208$ & 100.25 & 1.036 \\
\hline & 30 & $30.01 \pm 0.286$ & 100.04 & 0.953 & $30.12 \pm 0.286$ & 100.39 & 0.889 \\
\hline
\end{tabular}


Table (3): Determination of intact SFB in mixtures with its alkaline degradate by the proposed methods:

\begin{tabular}{|c|c|c|c|c|c|}
\hline Method & $\begin{array}{c}\text { Intact } \\
\left(\mu \mathrm{g} \mathrm{ml}^{-1}\right)\end{array}$ & $\begin{array}{c}\text { Degradate } \\
\left(\mu \mathrm{g} \mathrm{ml}^{-1}\right)\end{array}$ & $\begin{array}{c}\text { Degradate } \\
\%\end{array}$ & $\begin{array}{l}\text { Intact found } \\
\left(\mu \mathrm{g} \mathrm{ml}^{-1}\right)\end{array}$ & $\begin{array}{c}\text { Recovery } \% \text { of } \\
\text { Intact }\end{array}$ \\
\hline \multirow{7}{*}{ 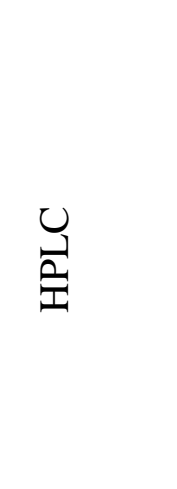 } & 30 & 5 & 14 & 29.57 & 98.57 \\
\hline & 25 & 10 & 29 & 25.00 & 100.00 \\
\hline & 20 & 15 & 43 & 20.03 & 100.14 \\
\hline & 15 & 20 & 57 & 15.30 & 101.99 \\
\hline & 10 & 25 & 71 & 10.15 & 101.53 \\
\hline & 5 & 30 & 86 & 5.09 & 101.71 \\
\hline & Mean \pm RSD $\%$ & & & & $100.66 \pm 1.310$ \\
\hline \multirow{7}{*}{ 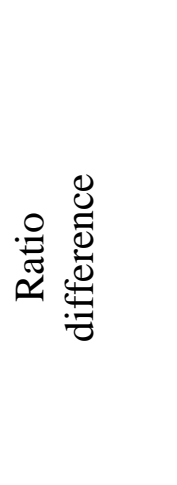 } & 30 & 5 & 14 & 30.51 & 101.71 \\
\hline & 25 & 10 & 29 & 25.22 & 100.89 \\
\hline & 20 & 15 & 43 & 20.33 & 101.64 \\
\hline & 15 & 20 & 57 & 15.29 & 101.94 \\
\hline & 10 & 25 & 71 & 10.23 & 102.30 \\
\hline & 5 & 30 & 86 & 4.89 & 97.74 \\
\hline & Mean \pm RSD $\%$ & & & & $101.04 \pm 1.662$ \\
\hline \multirow{7}{*}{ :욜 } & 30 & 5 & 14 & 30.24 & 100.80 \\
\hline & 25 & 10 & 29 & 25.11 & 100.44 \\
\hline & 20 & 15 & 43 & 20.31 & 101.55 \\
\hline & 15 & 20 & 57 & 15.21 & 101.40 \\
\hline & 10 & 25 & 71 & 10.20 & 102.00 \\
\hline & 5 & 30 & 86 & 5.17 & 103.40 \\
\hline & Mean \pm RSD $\%$ & & & & $101.06 \pm 1.026$ \\
\hline \multirow{7}{*}{ 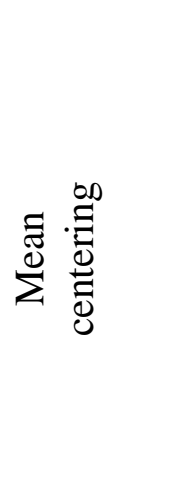 } & 30 & 5 & 14 & 30.18 & 100.60 \\
\hline & 25 & 10 & 29 & 25.35 & 101.40 \\
\hline & 20 & 15 & 43 & 20.18 & 100.90 \\
\hline & 15 & 20 & 57 & 14.95 & 99.70 \\
\hline & 10 & 25 & 71 & 9.93 & 99.30 \\
\hline & 5 & 30 & 86 & 4.97 & 100.60 \\
\hline & Mean \pm RSD $\%$ & & & & $99.92 \pm 1.374$ \\
\hline
\end{tabular}

Table (4): Determination of SFB in SOVALDI ${ }^{\circledR}$ tablets by the proposed and reported methods: 


\begin{tabular}{|c|c|c|c|c|c|}
\hline Parameters & HPLC & $\begin{array}{c}\text { Ratio } \\
\text { difference }\end{array}$ & $\begin{array}{c}\text { Ratio } \\
\text { derivative }\end{array}$ & $\begin{array}{c}\text { Mean } \\
\text { centering }\end{array}$ & $\begin{array}{c}\text { Reported } \\
\text { method** }\end{array}$ \\
\hline $\mathbf{N}^{*}$ & 5 & 5 & 5 & 5 & 5 \\
\hline $\mathbf{X}^{-}$ & 100.21 & 100.29 & 100.38 & 100.16 & 100.04 \\
\hline $\mathbf{S D}$ & 1.248 & 0.780 & 0.838 & 0.684 & 1.037 \\
\hline $\mathbf{R S D \%}$ & 1.245 & 0.777 & 0.835 & 0.683 & 1.037 \\
\hline $\mathbf{t}^{* * *}$ & 0.23 & 0.42 & 0.57 & 0.21 & \\
\hline $\mathbf{F}^{* * *}$ & $(2.31)$ & $(2.31)$ & $(2.31)$ & $(2.31)$ & \\
\hline & 1.45 & 1.77 & 1.53 & 2.30 & \\
\hline
\end{tabular}

* No. of experimental.

** It is an HPLC method using Zorbax phenyl (250 X 4.6 X $5 \mu$ m particle size) column and phosphate buffer $\mathrm{pH}$ 3.5: acetonitrile $(60: 40, v / v)$ as mobile phase at flow rate $1.5 \mathrm{ml} / \mathrm{min}$ and $U V$ detection at $260 \mathrm{~nm}$ (Al-AndalousCompany) .

*** The values in the parenthesis are tabulated values of $t$ and $F$ at $(p=0.05)$.

\section{CONCLUSION}

Simple, rapid, sensitive, accurate, precise and not expensive methods were developed for the analysis of SFB in pure form, in its tablets form and in presence of its alkaline degradation product. The sensitivity, reproducibility and simplicity of the proposed methods make them valuable in routine analysis of SFB. In addition, the proposed methods were found to be stability indicating methods.

\section{ACKNOWLEDGMENT}

I am deeply thankful to ALLAH, by the grace of whom this work was realized. I wish to express my indebtedness and gratitude to staff members Pharmaceutical Analytical Chemistry Department, Faculty of Pharmacy Al-Azhar University, Cairo, Egypt for their co-operation throughout the whole work.

\section{REFERENCES}

Abdallah, O. M; and Badawey, A. M. (2011): Int. J. Ind. Chem., 2(2): 78-85.

Afkhami, A; and Bahram, M. (2004): Anal. Chim. Acta, 526(2): 211-218.

Afkhami, A; and Bahram, M. (2005): Talanta, 66(3): 712-720.

Afkhami, A; and Bahram M. ( 2006): Talanta, 68(4): 1148-1155.

Al-Andalous Company: Quality control and quality assurance units "Al-Andalous for Pharmaceutical Industries Company, Giza, Egypt". (Personal communications)

Armitage, P; and Berry, G. (1994) : Statistical Methods in Medical Research. 3rd ed. Oxford, UK; Blackwell 
Belal, T. S; Daabees, H. G; Abdel-Khalek, M. M; Mahrous, M. S; and Khamis, M. M. (2013): J. Pharm. Anal., 3(2): 118-126.

British Pharmacopoeia (2012): The Stationery Office, Vol. 5. London, UK.

Connors, A. K (2005): A Text book of pharmaceutical analysis. 3rd ed. Hoboken (NJ): Wiley Interscience Publication.

Darwish, H. W; Hassan, S. A; Salem, M. Y; and El-Zeany, B. A. (2013): Spectrochimca Acta Part A: Mol. Biomol. Spectrosc., 104: 70-76.

Darwish, H.W; Hassan, S.A; Salem, M.Y; and El-Zeiny, B. A. (2011): Spectrochimca Acta Part A: Mol. Biomol. Spectrosc., 83(1): 140-148.

EL-Bagary, R. I; Abo-talib, N.F; and Nor-Eldin, M. B. (2011): J. Chem. Pharm. Re., 3(6): 562-570.

El-Ragehy, N. A; Abbas, S. S; and El-Khateeb, S. Z. (2002): Anal. Chim. Acta., 461: $155-168$.

Elzanfaly, E. S; Saad, A. S; Abd Elaleem, A. B. (2012): J. Pharm. Anal., 2(5): 382385 .

Harvey, D. (2000): Modern analytical chemistry. New York: McGraw-Hill.

ICH (2005): Validation of analytical procedure. Text and methodology. Geneva: International conference on Harmonization.

Issa, Y. M; Zayed, S. M; and Habib, I. I. (2011): Arabian J. Chem., 4: 259-263.

Lotfy, H. M; and Hagazy, M. A. (2012): Spectrochimca Acta Part A: Mol. Biomol. Spectros., 96: 259-270.

Lotfy, H. M; Saleh, S. S; Hassan, N. Y; and Elgizawy, S. M. (2012): J. Anal. Chem., 3: 761-769.

Martin, M; and Guiochon, G. (2005): J Chromatogr A., 1090(1-2): 16-38.

RxList (2015): the internet drug index [Internet]. California: WebMD; 2004. Sovaldi; [reviewed 2015 Jun 4; cited 2015 Jun 27]. Available from: http://www.rxlist.com/sovaldi-drug.htm

Willard, H. H; Dean, A. J. (1986): Instrumental Methods of Analysis. 7th ed. New Delhi: CBS Publishers and Distributors. 


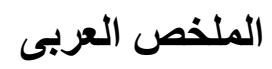

استخدام كروماتوجرافيا السوائل ذات الاداء العالي والمطياف الضوئي لتعيين ثباتية عقار

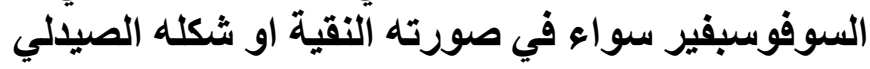

للسيد الدكتور

احمد عبد الحليم ابوسريع محمد

م-ســـ

قسم الكيمياء التحليلية كلية الصيدلة جامعة الاز هر بالقاهرة

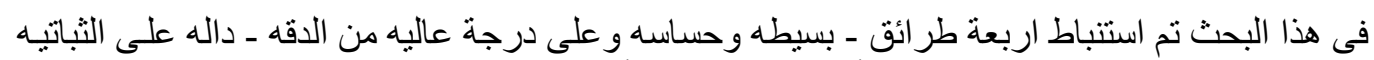

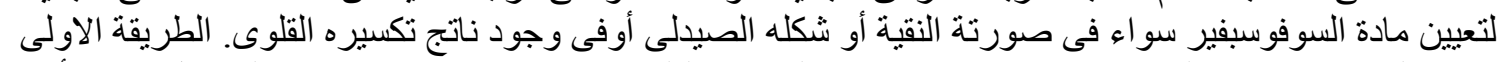

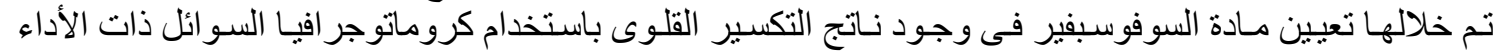

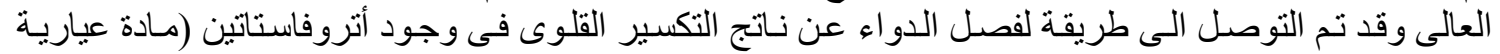

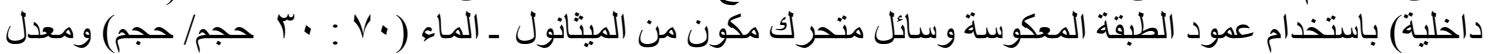

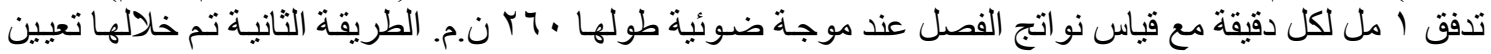

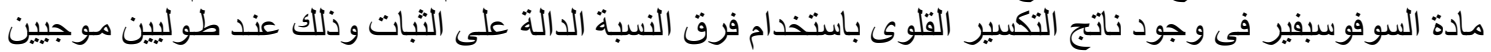

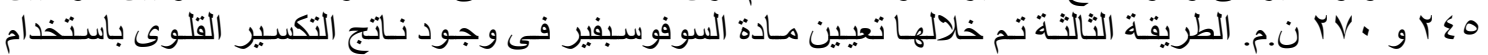

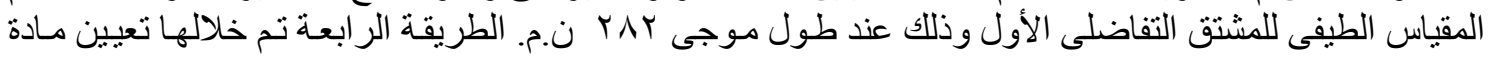

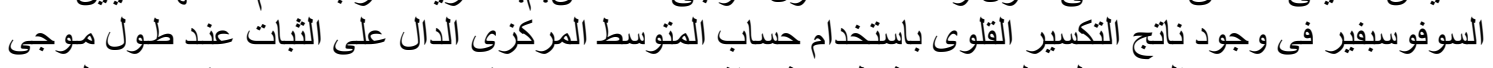

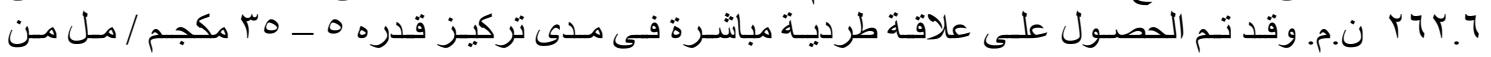

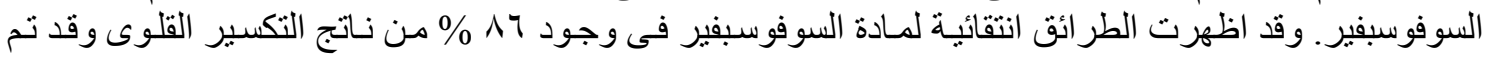
الحصول على نتائج دقيقة فى الإسترجاع حيث كانت

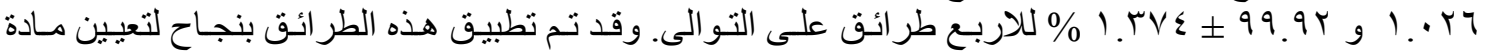

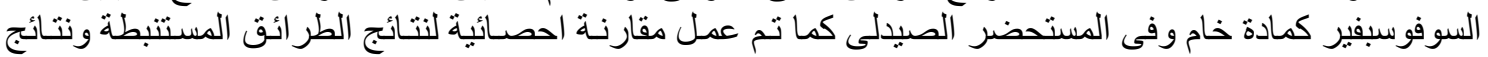
الطريقة المرجعية واتضح انه لا يوجد فرق من حيث الدقة و والضيط. 